\title{
Interactions of Actin, Myosin, and an Actin-Binding Protein of Chronic Myelogenous Leukemia Leukocytes
}

\author{
Laurence A. Boxer and Thomas P. Stossel \\ From the Division of Hematology-Oncology, Children's Hospital Medical \\ Center, The Sidney Farber Cancer Center, Department of Pediatrics, Harvard \\ Medical School, Boston, Massachusetts 02115
}

A B S T R A T Actin, myosin, and a high molecular weight actin-binding protein were purified from chronic myelogenous leukemia (CML) leukocytes. CML leukocyte actin resembled skeletal muscle and other cytoplasmic actins by its subunit molecular weight, by its ability to polymerize in the presence of salts, and to activate the $\mathrm{Mg}^{2+}$-ATPase activity of rabbit skeletal muscle myosin. CML leukocyte myosin was similar to other vertebrate cytoplasmic myosins in having heavy chains and two light subunits. However, its apparent heavy-chain molecular weight and Stokes radius suggested that it was variably degraded during purification. Purified CML leukocyte myosin had average specific EDTA- and $\mathrm{Ca}^{2+}$-activated ATPase activities of 125 and $151 \mathrm{nmol} \mathrm{P}_{1}$ released/mg protein per min, respectively and low specific $\mathrm{Mg}^{2+}$-ATPase activity. The $\mathrm{Mg}^{2+}$-ATPase activity of CML myosin was increased 200 -fold by rabbit skeletal muscle F-actin, but the specific activity relative to that of actin-activated rabbit skeletal muscle myosin was low. CML leukocyte myosin, like other vertebrate cytoplasmic myosins, formed filaments in $0.1 \mathrm{M} \mathrm{KCl}$ solutions. Reduced and denatured CML leukocyte-actin-binding protein had a single high molecular weight subunit like a recently described actinbinding protein of rabbit pulmonary macrophages which promotes the polymerization and gelation of actin.

Cytoplasmic extracts of CML leukocytes prepared with ice-cold 0.34-M sucrose solutions containing $\mathrm{Mg}^{2+}$ ATP, dithiothreitol, and EDTA at $\mathrm{pH} 7.0$ underwent rapid gelation when warmed to $25^{\circ} \mathrm{C}$. Initially, the gel could be liquified by cooling to ice-bath temperature.

Dr. Stossel is an Established Investigator of The American Heart Association. Dr. Boxer's present address is Department of Pediatrics, University of Indiana School of Medicine, Indianapolis, Ind. 46202.

Received for publication 21 July 1975 and in revised form 1 December 1975.
With time, warmed cytoplasmic extract gels shrunk ("contracted") into aggregates. The following findings indicated that CML leukocyte actin-binding protein promoted the temperature-dependent gelation of actin in the cytoplasmic extracts and that CML leukocyte myosin was involved in the contraction of the actin gels: (a) Cytoplasmic extract gels initially contained actin as their major polypeptide component and consisted of tangled thin filaments; $(b)$ Contracted aggregates of cytoplasmic extract gels contained large quantities of myosin as well as actin; (c) Purified actin-binding protein underwent a temperature-dependent, reversible aggregation and caused low concentrations of purified muscle or CML leukocyte actins to gel in sucrose solutions; (d) The gels formed from purified actin plus purified actin-binding protein slowly contracted in the presence but not in the absence of purified CML leukocyte myosin; (e) Rabbit antiserum against purified CML leukocyte actin-binding protein but not against purified CML leukocyte myosin inhibited the gelation of warmed CML leukocyte extracts. Antiserum against CML leukocyte myosin had no effect on the gelation of CML leukocyte extracts but partially curtailed the contraction of the CML leukocyte extract gels and of gels formed from purified CML leukocyte actin-binding protein plus rabbit skeletal muscle actin.

\section{INTRODUCTION}

Movement characterizes most of the activities of neutrophilic polymorphonuclear leukocytes. They crawl actively like amebas throughout the tissues of the body where they extend pseudopodia to surround and interiorize various objects, while granules stream and tumble in the cytoplasm (1). It was suggested many years ago that the mechanisms of muscle and leukocyte movement might be similar (2), and recent work has given some validity to this idea. Senda et al. prepared frac- 
tions of equine blood leukocytes which they believed had morphologic and functional properties which resembled those of muscle proteins (3-5). The subsequent purification or unequivocal demonstration of myosin and actin of guinea pig, human, and horse polymorphonuclear leukocytes established the correctness of their conclusions (6-8).

However, only a systematic analysis of the properties of contractile proteins in neutrophils and scrutiny of their interactions will establish definitively whether they are actually involved in leukocyte movement, and if so, in what way. This report describes the isolation and some properties of actin, myosin, and a high molecular weight actin-binding protein from neutrophil leukocytes of patients with chronic myelogenous leukemia (CML). ${ }^{1}$ An abstract of this work has been published (9).

\section{METHODS}

CML leukocytes. For each preparation of proteins, 5-10 $\times 10^{10}$ leukocytes were removed from one of two patients with CML undergoing treatment by continuous flow centrifugation leukaphoresis (10). Erythrocytes were removed from the leukocytes by sedimentation with dextran and lysis with ammonium chloride (11). The leukocytes were washed two times with $30 \mathrm{vol}$ of ice-cold $0.15 \mathrm{M}$ sodium chloride by centrifugation at $80 \mathrm{~g}$ for $10 \mathrm{~min}$. An average of $200 \mathrm{ml}$ of packed cells was collected from each leukaphoresis, and 70$80 \%$ of the cells were neutrophilic polymorphonuclear leukocytes, metamyelocytes, and band forms. The rest of the cells were blasts $(2-3 \%)$, promyelocytes $(2-3 \%)$, myelocytes (5-10\%), and lymphocytes (5-10\%). Approximately 75 leukocytes were seen per platelet by microscopic examination of Wright's-stained smears.

$C M L$ extracts. Packed leukocytes were suspended in 2 vol of a solution containing $0.34 \mathrm{M}$ sucrose, $10 \mathrm{mM}$ dithiothreitol, $5 \mathrm{mM}$ ATP, $1 \mathrm{mM}$ EDTA, and $20 \mathrm{mM}$ Trismaleate buffer, pH 7.0 (sucrose solution), and broken in the cold $\left(4^{\circ} \mathrm{C}\right)$ by grinding for 7 min with a Potter-Elvehjem homogenizer with a motor-driven Teflon pestle followed by 45 strokes with a tight-fitting pestle in a glass Dounce homogenizer. In some experiments, the cells suspension was broken in the cold $\left(4^{\circ} \mathrm{C}\right)$ in a chilled Waring blendor (Waring Products Div., Dynamics Corp. of America, New Hartford, Conn.), the blades of which were rotated at $20,000 \mathrm{rpm}$ for $3 \mathrm{~min}$. These procedures caused rupture of all cells as monitored by phase microscopy. The homogenates, which contained an average of $42.5 \mathrm{mg}$ of protein $/ \mathrm{ml}$ of packed cells, were centrifuged at $40,000 \mathrm{~g}$ $1 \mathrm{~h}$. The supernates were centrifuged at $100,000 \mathrm{~g}$ for $1 \mathrm{~h}$ yielding a clear supernate (extract supernate) and a pellet which was discarded. The extract supernate, which contained about $69 \%$ of the homogenate protein, had an initial $\mathrm{pH}$ of 6.4 that was adjusted to $\mathrm{pH} 7.4$ by addition of 0.1 $\mathrm{M} \mathrm{NaOH}$. Actin, myosin, and an actin-binding protein were isolated from the extract supernate as described below.

Preparation of $C M L$ actin. The extract supernate was warmed to $25^{\circ} \mathrm{C}$ and left standing at room temperature for $2 \mathrm{~h}$. An opalescent, gelatinous precipitate formed and was collected by centrifugation at $49,000 \mathrm{~g}$ for $20 \mathrm{~min}\left(4^{\circ} \mathrm{C}\right)$.

${ }^{1}$ Abbreviations used in this paper: CML, chronic myelogenous leukemia; EGTA, ethylene glycol bis $(\beta$-aminoethyl ether) $-N, N^{\prime}$-tetraacetic acid.
The supernatant fluid was saved for isolation of CML myosin. The precipitate was dissolved with approximately $2 \mathrm{ml}$ ice-cold $0.6 \mathrm{M} \mathrm{KCl}$ containing $20 \mathrm{mM}$ Tris-maleate buffer, pH 7.0, per $\mathrm{mg}$ of precipitate protein. The solution was centrifuged for $3 \mathrm{~h}$ at $80,000 \mathrm{~g}\left(4^{\circ} \mathrm{C}\right)$, and the supernate was used to prepare actin-binding protein. The opalescent pellet was dissolved in a glass-tissue grinder with a small volume of a solution containing $0.2 \mathrm{mM}$ ATP, $10 \mathrm{mM}$ dithiothreitol, $0.2 \mathrm{mM} \mathrm{CaCl}, 2 \mathrm{mM}$ Tris- $\mathrm{HCl}$, pH 7.0 (depolymerizing buffer [12]) and was depolymerized and repolymerized as described by Spudich and Watt for the preparation of skeletal muscle actin (12). The purified CML actin pellet was dissolved in $10 \mathrm{mM}$ Tris-maleate solution, pH 8.0, containing $2 \mathrm{mM} \mathrm{MgCl}_{2}$ or lyophilized in the depolymerized state before a final polymerization.

Preparation of CML myosin. The supernatant fluid remaining after removal of the precipitate that formed in the warmed extract supernate was made $75 \mathrm{mM}$ in $\mathrm{KCl}$ and stirred with a magnetic stirrer for $1.5 \mathrm{~h}$. The solution was centrifuged at $80,000 \mathrm{~g}$ for $3 \mathrm{~h}\left(4^{\circ} \mathrm{C}\right)$, and the resulting pellet was dissolved in an ice-cold solution containing $0.6 \mathrm{M}$ $\mathrm{KCl}, 0.5 \mathrm{mM}$ ATP, $5 \mathrm{mM}$ dithiothreitol, and $20 \mathrm{mM}$ Trismaleate buffer, $\mathrm{pH} 7.0$ ( $\mathrm{KCl}$ solution) with the aid of a glass-tissue grinder. The $\mathrm{KCl}$ solution was fractionated with ice-cold saturated ammonium sulfate containing $0.01 \mathrm{M}$ EDTA, $\mathrm{pH}$ 7.0. Of the total $\mathrm{K}^{+}$- and EDTA-activated ATPase activity of the extract supernate, used as an enzymatic marker for myosin, $59 \%$ was collected in a $20-50 \%$ saturated ammonium sulfate fraction. This precipitate was dissolved in and dialyzed against an ice-cold $\mathrm{KCl}$ solution and stored in $50 \%$ saturated ammonium sulfate solution $\left(4^{\circ} \mathrm{C}\right)$.

The precipitated proteins were redissolved and dialyzed free of ammonium sulfate with $\mathrm{KCl}$ solution and applied to $2.5 \times 80-\mathrm{cm}$ columns of Bio-Gel A 15-M (Bio-Rad Laboratories, Richmond, Calif.) 200-400 mesh (4\% agarose) and eluted in the cold $\left(4^{\circ} \mathrm{C}\right)$ with $\mathrm{KCl}$ solution. Eluted fractions with $\mathrm{K}^{+}$- and EDTA-activated ATPase activity were pooled, concentrated in a dialysis sac in dry Sephadex G-200, (Pharmacia Fine Chemicals, Inc., Piscataway, N. J.) and dialyzed against a solution containing $0.6 \mathrm{M} \mathrm{KI}, 10 \mathrm{mM}$ sodium thiosulfate, $5 \mathrm{mM} \mathrm{ATP}, 5 \mathrm{mM}$ dithiothreitol, and $20 \mathrm{mM}$ Tris-maleate buffer, $\mathrm{pH} \quad 7.0$ (KI solution). The dialyzed protein solutions were chromatographed on $4 \%$ agarose columns equilibrated with $\mathrm{KI}$ and $\mathrm{KCl}$ solutions according to the technique of Pollard et al. (13). The proteins were eluted at $4^{\circ} \mathrm{C}$ with $\mathrm{KCl}$ solution. Eluted fractions with $\mathrm{K}^{+}$- and EDTA-activated ATPase activity were pooled and concentrated as described above.

Preparation of CML actin-binding protein. After actin was removed by ultracentrifugation from the washed gelatinous precipitate of the warmed extract supernate, the remaining material in the $0.6-\mathrm{M} \mathrm{KCl}$ solution was dialyzed against KI solution and applied to columns of Bio-Gel A 15M 200-400 mesh equilibrated with $\mathrm{KI}$ and $\mathrm{KCl}$ solutions as described for the preparation of myosin. Peaks of absorbance at $290 \mathrm{~nm}$ were pooled and concentrated with dry Sephadex G-200.

Preparation of proteins from rabbit skeletal muscle. Myosin was prepared by the second method of Kielley and Bradley (14) and purified further by ion-exchange chromatography (15). F-actin was made by the technique of Spudich and Watt (12).

Assay of ATPase activity. Assays of EDTA- and $\mathrm{Ca}^{2+}$ activated ATPase activity in $0.6 \mathrm{M} \mathrm{KCl}$ (called $\mathrm{K}^{+}$- and EDTA-activated and $\mathrm{K}^{+}-$and $\mathrm{Ca}^{2+}$-activated ATPase ac-

Interactions of Leukemic Contractile Proteins 965 


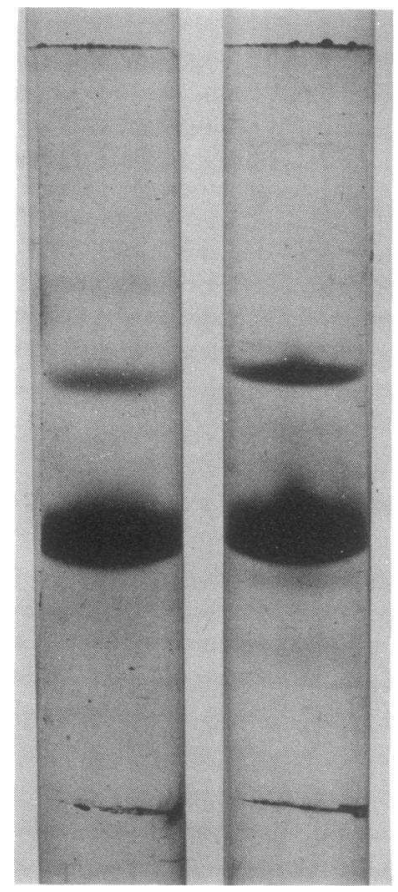

FIGURE 1 Dodecyl sulfate $5 \%$ polyacrylamide gel electrophoretograms of reduced purified rabbit skeletal muscle actin (left) and purified CML actin (right).

tivities, respectively) and of $\mathrm{Mg}^{2+}$-ATPase activity in 0.02 $\mathrm{M} \mathrm{KCl}$ in the presence or absence of ethylene glycol bis $(\beta-$ aminoethyl ether) $-N, N^{\prime}$-tetraacetic acid (EGTA) or $\mathrm{CaCl}_{2}$ were performed as previously described (6). Protein was assayed by the Folin procedure (16) with bovine serum albumin as the standard.

Dodecyl sulfate-polyacrylamide gel electrophoresis. Protein samples were dialyzed against distilled water and lyophilized. Some proteins were reduced and alkylated with iodoacetate (17) before dialysis. The dried proteins were prepared for electrophoresis on $5 \%$ polyacrylamide gels with $0.125 \%$ cross-linker according to the technique of Fairbanks et al. (18). Electrophoretograms of whole CML leukocytes were prepared by dissolving cells in gel sample buffer at $37^{\circ} \mathrm{C}$ for $2 \mathrm{~h}$ and $100^{\circ} \mathrm{C}$ for $5 \mathrm{~min}$. The gels were stained overnight with brilliant Coomassie Blue in isopropanol and destained in a Hoefer apparatus (Hoefer Scientific Instruments, San Francisco, Calif.) containing Bio-Rad $\mathrm{Rb} 501-\mathrm{X} 820-50$ mesh resin in $10 \%$ acetic acid. The relative mobilities of the test and standard proteins, which included rabbit skeletal muscle myosin and actin, human erythrocyte spectrin, beef liver catalase, bovine serum albumin, Escherichia coli $\beta$-galastosidase, porcine chymotrypsinogen, and yeast cytochrome $c$, were calculated as described by Weber and Osborn (19). Gels were scanned by means of a Linear Instruments Corporation (Irvine, Calif.) scanning device and recorder, and absorbance at $554 \mathrm{~nm}$ was monitored.

Preparation of antisera and immunochemical analysis. Purified CML leukocyte myosin, actin-binding protein, and a fragment of myosin were emulsified with complete Freund's adjuvant, and $20-40 \mu \mathrm{g}$ of the protein was injected subcutaneously into rabbits. Booster injections of $20-40 \mu \mathrm{g}$ were given weekly until precipitating antibodies were detected, usually after 6-8 wk. Double diffusion was performed on microscope slides containing $1 \%$ agar gel pre- pared with a $0.25-\mathrm{M} \mathrm{KCl}$ solution containing $20 \mathrm{mM}$ Trismaleate buffer, $\mathrm{pH}$ 7.0. The proteins were allowed to react in a humidified atmosphere at $25^{\circ} \mathrm{C}$ overnight. All slides were then washed in $0.15 \mathrm{M} \mathrm{NaCl}$ containing $15 \mathrm{mM}$ sodium phosphate, $\mathrm{pH} 7.0$, stained with $1 \%$ Amido-Schwartz in $5 \%$ acetic acid and $50 \%$ methanol, and destained with $5 \%$ glycerol and $2 \%$ acetic acid in $5 \%$ methanol.

Studies of morphology. Proteins were negatively stained on grids with uranyl acetate. Intact CML cells, gelatinous precipitates of CML leukocyte extracts, or gels formed from purified CML proteins were fixed in $2.5 \%$ glutaraldehyde and $0.1 \mathrm{M}$ sodium cacodylate at $25^{\circ} \mathrm{C}$, postfixed with Dalton's chrome osmium and $1 \%$ uranyl acetate, dehydrated with acetone, and embedded in Epon-Araldite. Thin sections were stained with lead citrate. Grids were examined and photographed in a Phillips 300 electron microscope (Amsterdam, Netherlands) with accelerating voltage of $60 \mathrm{kV}$.

Turbidometry. The turbidity of extract supernates or of purified proteins was assayed spectrophotometrically at 350 $\mathrm{nm}$ in $0.5-\mathrm{ml}$ quartz cuvettes (6). The temperature of the solutions was maintained by a water-jacket carrier in the Gilford Instruments Laboratories, Inc. (Oberlin, Ohio) spectrophotometer.

Materials. Crystalline bovine serum albumin was purchased from Armour (Armour Industrial Chemical Co., Chicago, Ill.), catalase was from Worthington (Worthington Biochemical Corp., Freehold, N. J.), dithiothreitol, disodium ATP, and $\beta$-galactosidase were from Sigma (Sigma Chemical Co., St. Louis, Mo.). Human erythrocyte spectrin and goat antihuman spectrin IgG were generously provided by Samuel E. Lux, M.D., Children's Hospital Medical Center, Boston, Mass.

\section{RESULTS}

The contractile proteins of CML leukocytes. (a) $C M L$ actin. A polypeptide that co-migrated with rabbit skeletal muscle actin comprised $11 \%$ of the reduced, denatured, stainable protein in the extract supernate as determined by quantitative densitometry after electrophoresis with polyacrylamide gels. The densitometric estimates are only approximate since the relative staining intensities of all CML proteins is unknown and other proteins may contribute to the "actin" band. 0.24 $0.48 \mathrm{mg}$ of pure actin was recovered from each gram of homogenate protein.

Purified CML actin in dodecyl sulfate yielded a band that comprised $80 \%$ of the stainable protein on polyacrylamide gels and that co-migrated with the major band in reduced and denatured skeletal muscle actin (Fig. 1). A band comprising $15 \%$ of the stainable protein of heavily loaded gels containing the CML actin and corresponding to a mol wt of 80,000 was observed on gels prepared with both skeletal muscle and CML actin and presumably represented actin dimers.

Purified CML F-actin increased the $\mathrm{Mg}^{2+}$-ATPase activity of rabbit skeletal muscle myosin by 10 -fold (Fig. 2). The $\mathrm{Mg}^{2+}$-ATPase activity of muscle myosin activated by macrophage actin was not influenced by 1 $\mathrm{mM}$ EGTA or by $0.2 \mathrm{mM} \mathrm{CaCl}$ under the conditions of the present study. 

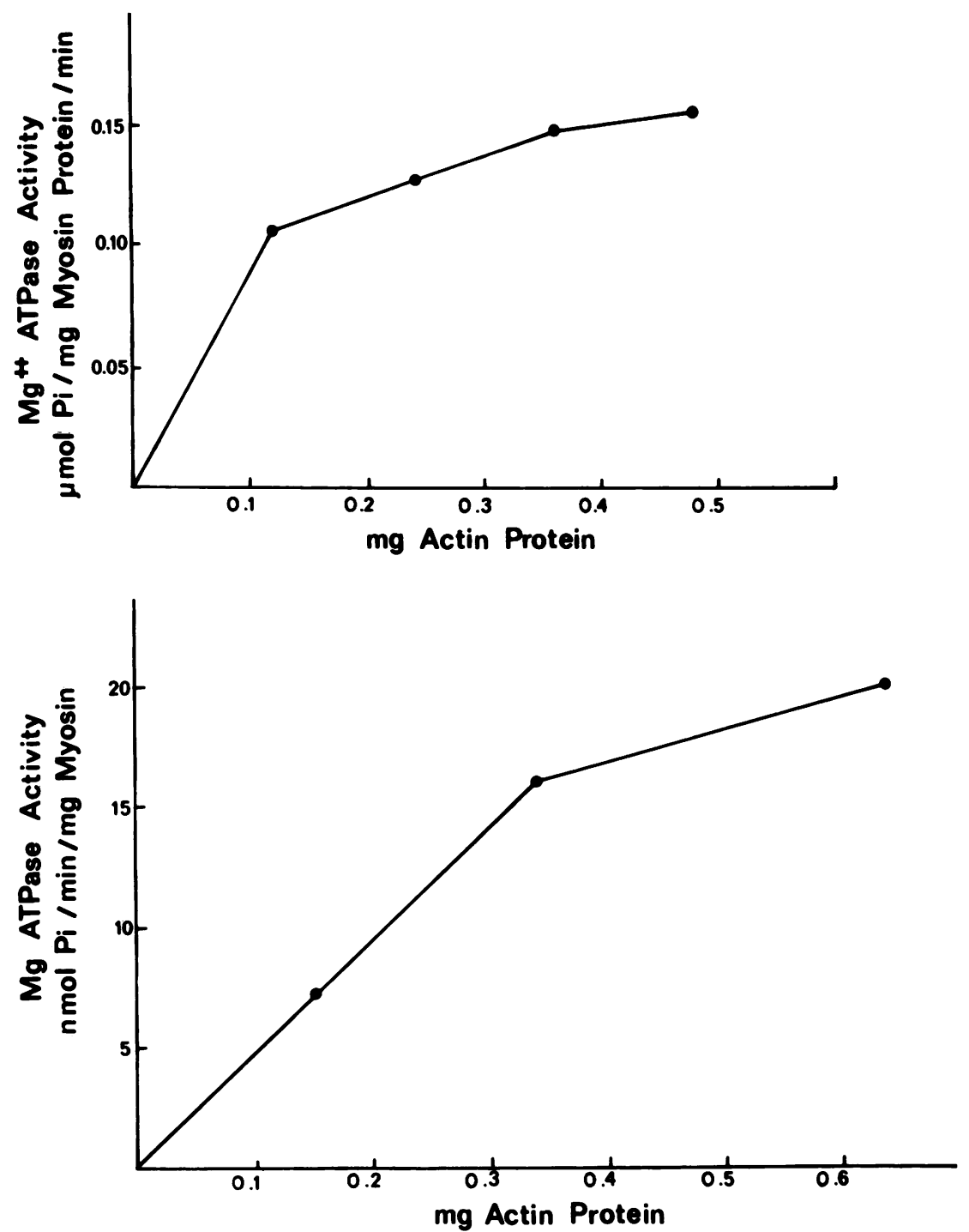

FIgURE 2 (Top) Effect of purified CML actin on $\mathrm{Mg}^{2+}$-ATPase activity of $0.12 \mathrm{mg}$ of rabbit skeletal muscle myosin in $0.5 \mathrm{ml}$ of $20 \mathrm{mM} \mathrm{KCl}, 10 \mathrm{mM}$ Tris-maleate solution, $\mathrm{pH}$ 7.0. The $\mathrm{Mg}^{2+}$-ATPase activity of the muscle myosin in the absence of added actin $\left(15 \mathrm{nmol} \mathrm{P}_{1} / \mathrm{min}\right.$ per $\mathrm{mg}$ myosin protein) has been subtracted from the indicated activities. (Bottom) Effect of rabbit skeletal muscle actin concentrations on the $\mathrm{Mg}^{2+}$-ATPase activity of $0.09 \mathrm{mg}$ of purified CML myosin in $0.5 \mathrm{ml}$ of $20 \mathrm{mM} \mathrm{KCl}, 10 \mathrm{mM}$ Tris-maleate solution, $\mathrm{pH} 7.0$. The $\mathrm{Mg}^{2+}$ ATPase activity of the CML myosin in the absence of added actin $\left(0.1 \mathrm{nmol} \mathrm{P}_{1} / \mathrm{min}\right.$ per $\mathrm{mg}$ myosin protein) has been subtracted from the indicated activities.

(b) $C M L$ myosin. $\mathrm{K}^{+}$- and EDTA-activated ATPase activity was present in extract supernates. The majority of the enzyme activity was found in a $20-50 \%$ saturated ammonium sulfate fraction. Little purification of the enzyme activity was achieved by ammonium sulfate precipitation, but the protein could be stored at $4^{\circ} \mathrm{C}$ without loss of activity at this step. The enzyme activity eluted from agarose columns equilibrated with $\mathrm{KCl}$ and $\mathrm{KI}-\mathrm{KCl}$ solutions with a partition coefficient of $0.19 \pm 0.05$ (mean $\pm \mathrm{SD}$ ) which was reproducibly greater than the partition coefficient of rabbit skeletal myosin (0.18). This fraction was called "CML myosin." When the extract supernate was allowed to remain overnight at $4^{\circ} \mathrm{C}$ before further purification, $\mathrm{K}^{+}$- and EDTA-activated ATPase activity eluted with a partition coefficient of 0.63 . This material was designated "CML myosin fragment." Myosin from CML extracts, processed rapidly to the point of fractionation with ammonium sulfate, did not undergo such complete fragmentation.

The yield of CML myosin ranged from 0.16 to 0.48 $\mathrm{mg} / \mathrm{g}$ of homogenate protein during three isolations,

Interactions of Leukemic Contractile Proteins 


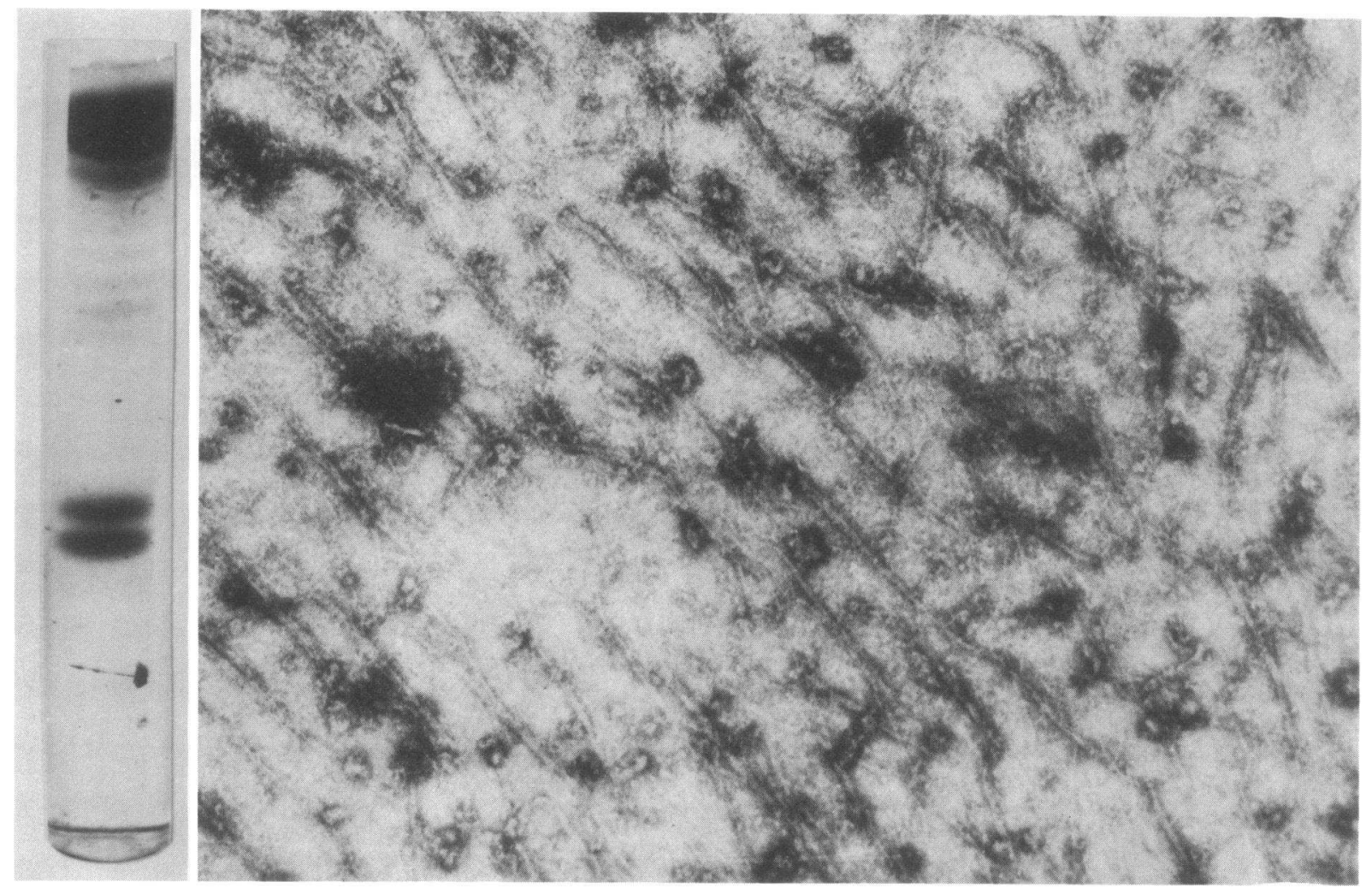

FIGURE 3 Dodecyl sulfate $5 \%$ polyacrylamide gel electrophoretogram of purified reduced CML myosin and electron micrograph of purified CML myosin suspended in $0.1 \mathrm{M} \mathrm{KCl}$ and $20 \mathrm{mM}$ Tris-maleate buffer, $\mathrm{pH} 7.0$, and negatively stained with uranyl acetate. Magnification $\times 88,000$.

and an average of $80 \%$ of the total $\mathrm{K}^{+}$- and EDTAactivated ATPase in the extract supernate was recovered. $0.36 \mathrm{mg}$ of myosin fragment was recovered per gram of homogenate protein or $54 \%$ of the total $\mathrm{K}^{+}-$ and EDTA-activated ATPase activity of the extract supernate.

Purity and subunit composition of purified CML myosin were assessed by electrophoresis on $5 \%$ polyacrylamide gels in the presence of sodium dodecyl sulfate. The CML myosin contained a major band of mol wt 175,000 (Fig. 3). Two other bands had mol wt of 18,000 and 15,000 , respectively. Electrophoretograms of the extract supernate contained heavy polypeptides that were larger than the heavy subunit of the purified CML myosin but were slightly smaller than the heavy chain of rabbit skeletal muscle myosin. This suggested that the CML myosin heavy chain was progressively degraded during isolation. CML myosin formed filaments in $0.1 \mathrm{M}$ $\mathrm{KCl}$ that had a fibrous shaft and numerous projections (Fig. 3). Some of the CML myosin filaments were 240 $\mathrm{nm}$ long and clearly bipolar, but most were of variable length. The shafts were 8-14 $\mathrm{nm}$ wide.

Like other myosins, CML myosin and CML myosin fragment had ATPase activity that was activated by EDTA or $\mathrm{Ca}^{2+}$ in the presence of $0.6 \mathrm{M} \mathrm{KCl}(125 \pm 7$ and $151 \pm 10 \mathrm{nmol} \mathrm{P}_{1}$ released/mg protein per min at $37^{\circ} \mathrm{C}$, respectively; mean $\pm \mathrm{SD}$ for three preparations). Rabbit skeletal muscle actin increased the negligible $\mathrm{Mg}^{2+}$-ATPase activity of CML myosin at low ionic strength (Fig. 2), but, compared to actin-activated skeletal muscle myosin, the specific ATPase activity was low.

CML actin-binding protein. CML leukocyte had a polypeptide which migrated on dodecyl sulfate gels more slowly than skeletal muscle myosin heavy chain and constituted $1.0 \%$ of the total stainable protein. This protein was purified from CML leukocyte extracts (Fig. 4). The protein eluted in the void volume of agarose columns equilibrated with $\mathrm{KI}-\mathrm{KCl}$ solutions and also in the included volume with a partition coefficient of 0.31 . The yield of the protein averaged $0.35 \mathrm{mg} / \mathrm{g}$ of homogenate. During electrophoresis in dodecyl sulfate on $5 \%$ polyacrylamide gels, the protein obtained from both column elution positions migrated as a single major band (Fig. 4). In some preparations this band co-migrated with the lighter band of the doublet comprising human erythrocyte spectrin, but in most preparations its migration was slower than either of the spectrin subunits. The high molecular weight protein precipitated in $5 \mathrm{mM} \mathrm{CaCl}_{2}$ and had no detectable $\mathrm{K}^{+}$- 


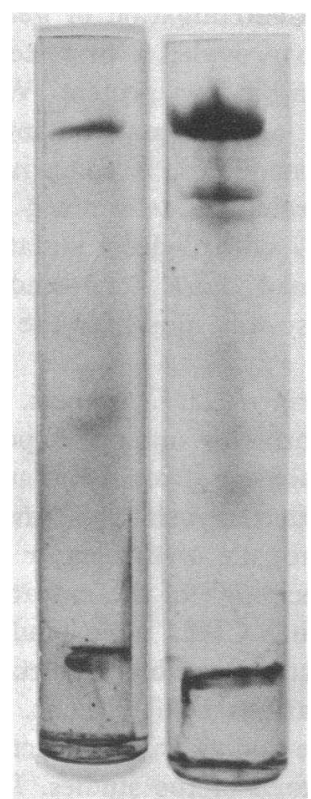

Figure 4 Dodecyl sulfate $5 \%$ polyacrylamide gel electrophoretograms of two preparations of CML actin-binding protein eluted from a $\mathrm{KI}-\mathrm{KCl}$ agarose column. The band below the major polypeptide component of the gel on the right is the heavy chain of CML myosin.

and EDTA-activated ATPase activity. On the basis of its similarities to a previously described "actin-binding protein" of rabbit alveolar macrophages $(20,21)$, this protein was designated "CML actin-binding protein."

Antibodies to CML myosin, actin-binding protein, and erythrocyte spectrin (Fig. 5). Antiserum to CML myosin yielded a major and several minor precipitin bands during double diffusion on agar gels. Several precipitin lines between myosin and antimyosin wells have been noted previously in some studies employing muscle myo-

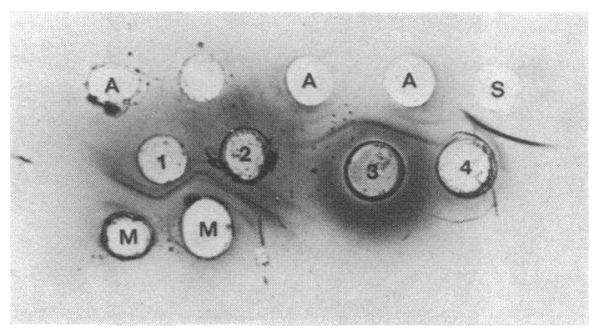

FIGURE 5 Reaction of rabbit antisera against CML leukocyte contractile proteins and of goat antihuman erythrocyte spectrin IgG with CML leukocyte proteins and with human erythrocyte spectrin. Antisera: 1) rabbit antiserum against CML myosin: 2) rabbit antiserum against CML myosin fragment; 3) rabbit antiserum against CML actin-binding protein; 4) goat IgG against human erythrocyte spectrin; antigens: $\mathrm{A}, \mathrm{CML}$ actin-binding protein; $\mathrm{M}$, two separately purified CML myosin preparations; S, purified human erythrocyte spectrin.

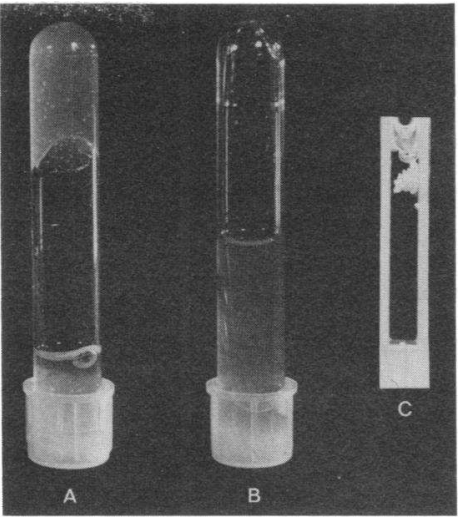

FiguRE 6 Reversible gelation and final contraction of warmed CML leukocyte supernatant extracts in sucrose solution. A, CML leukocyte extract supernate gelled by warming to $25^{\circ} \mathrm{C}$ for $45 \mathrm{~min}$; $\mathrm{B}$, previously gelled CML supernate which partially liquified after cooling for $120 \mathrm{~min}$ at $0^{\circ} \mathrm{C} ; \mathrm{C}$, final contraction of a gel into an aggregate in a cuvette.

$\sin (22)$. Antiserum against the myosin fragment reacted with the native CML myosin. Neither antiserum against CML myosin nor against the myosin fragment reacted with CML actin-binding protein or with erythrocyte spectrin. CML actin-binding protein antiserum formed heavy and light precipitin lines with CML actinbinding protein and did not react with erythrocyte spectrin or against CML myosin. Goat antihuman erythrocyte spectrin IgG yielded a single precipitin line with erythrocyte spectrin and did not react with CML actinbinding protein or with CML myosin.

Behavior of extract supernates of CML cells. Extracts of CML cells, in $0.34 \mathrm{M}$ sucrose containing $5 \mathrm{mM}$ dithiothreitol, $1 \mathrm{mM}$ ATP, $1 \mathrm{mM}$ EDTA, and $20 \mathrm{mM}$ Tris-maleate buffer, $\mathrm{pH} 7.0$ (sucrose solution), gelled when warmed from $4^{\circ}$ to $25^{\circ} \mathrm{C}$ (Fig. 6). A semiquantitative measurement of the gelation was achieved by visually determining the time required for

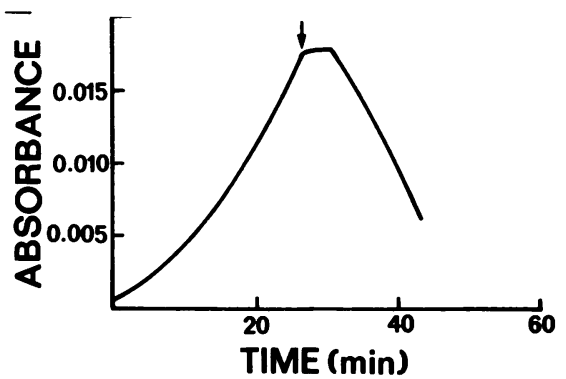

FIGURE 7 Effect of warming on the turbidity (absorbance at $350 \mathrm{~nm}$ ) of a CML leukocyte extract supernate in sucrose solution. At zero time, the extract was removed from an icebath and incubated at $25^{\circ} \mathrm{C}$. The temperature of water circulating through the cuvette holder was lowered to $0^{\circ} \mathrm{C}$ at the time indicated by the arrow.

Interactions of Leukemic Contractile Proteins 


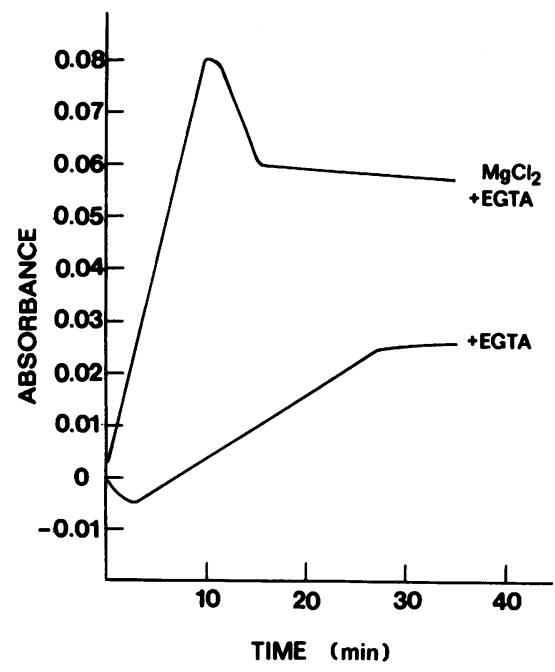

FIGURE 8 Effect of $\mathrm{MgCl}_{2}$ on the temperature-dependent changes in turbidity of a CML leukocyte extract supernate in the presence of EGTA. At zero time, the ice-cold supernates containing $1 \mathrm{mM}$ EDTA and $3 \mathrm{mM}$ EGTA, with or without added $\mathrm{MgCl}_{2}(5 \mathrm{mM})$, were incubated at $25^{\circ} \mathrm{C}$. The abrupt decrease in absorbance was associated with final contraction of the gel. The turbidity of the solutions was adjusted to zero with the slit at zero time. Negative readings represent a decrease in turbidity below this initial value.

the supernatant extract to become immobile when tilted back and forth in a tube. Viscometry was not suitable for quantifying gelation since the gel was disrupted into chunks during manipulation. Since the turbidity of extract supernates increased during gelation, the reaction was monitored spectrophotometrically (Fig. 7). During a 4- to 6-h period the gel contracted away from the sides of the container and shrunk into the center, finally forming a compact aggregate, which floated in liquid which was squeezed out of the gel (Fig. 6). Thus, the optical density of the extract supernate diminished as the gel in the cuvette aggregated. This decrease in turbidity was used to mark the onset of aggregation which we called "final contraction." If the gelled extracts were cooled before final contraction, the turbidity decreased (Fig. 7), and the gels liquified (Fig. 6 ). Extracts liquified by cooling, gelled again when warmed a second time. The total protein of a completely reliquified extract was not diminished by ultracentrifugation at $80,000 \mathrm{~g}$ for $3 \mathrm{~h}$, and no filaments were seen in the electron microscope.

Addition of $4 \mathrm{mM} \mathrm{MgCl}_{2}$ to the extract supernate increased the gelation rate and hastened the onset of final contraction (Fig. 8). Gelation and final contraction of extracts containing $1 \mathrm{mM}$ EDTA-5 mM $\mathrm{MgCl}_{2}$ were equivalent in the absence or presence of $3 \mathrm{mM}$ EGTA.

Protein composition of extract supernatant gel and contracted aggregates. Actin and actin-binding protein as well as other proteins were components of gelled ex- tract supernates. Centrifugation of gelled extracts early in their formation provided a first step in the isolation of actin and actin-binding protein. With time, myosin was incorporated into the supernatant gels, and, when contraction was completed, it comprised a major fraction of the total protein as determined by polyacrylamide gel electrophoresis with dodecyl sulfate. Whereas early actin gels contained more actin-binding protein than myosin, the reverse was found for the contracted aggregates (Fig. 9).

Behavior of purified CML proteins. The sequence of incorporation of proteins into the supernatant gels suggested that actin-binding protein and actin were involved in gelation, and that myosin was involved in contraction. To verify the role of the major peptides found in the gelatinous precipitate of the extract supernate, purified $\mathrm{CML}$ myosin, CML actin-binding protein, and either CML G-actin or rabbit skeletal muscle G-actin were mixed in various combinations. The protein concentrations of the individual contractile proteins were kept constant in each of the studies. During the warming of the rabbit skeletal muscle G-actin, or CML actinbinding protein, or a combination of rabbit skeletal muscle actin and CML myosin at a molar ratio of $33: 1$ in the sucrose solution, the turbidity of various solutions increased slightly, but gelation did not occur (Fig. 10). The addition of either rabbit skeletal muscle actin or CML G-actin to CML actin-binding protein at a molar ratio of $13: 1$ or $40: 1$, respectively resulted in a gel. The combination of the muscle G-actin and CML actinbinding protein increased the turbidity of the mixture beyond that observed for the actin-binding protein alone.

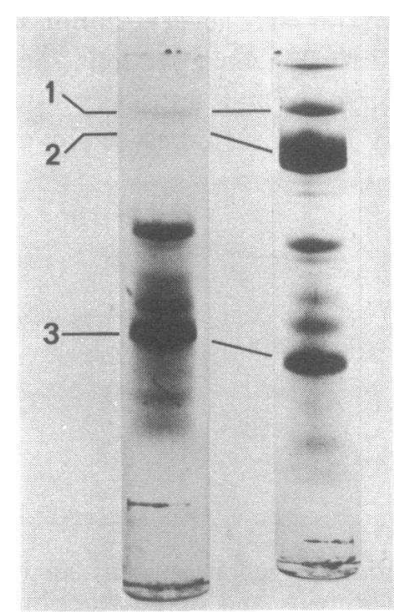

FIGURE 9 Dodecyl sulfate $5 \%$ polyacrylamide gel electrophoretograms of (left) CML extract gel collected by centrifugation at $24,000 \mathrm{~g}$ for $15 \mathrm{~min}$ after the extract was incubated at $25^{\circ} \mathrm{C}$ for $60 \mathrm{~min}$; (right) contracted aggregate from a CML leukocyte supernate. Polypeptides corresponding to actin-binding protein, myosin heavy chain, and actin are indicated by numbers $1-3$, respectively. 


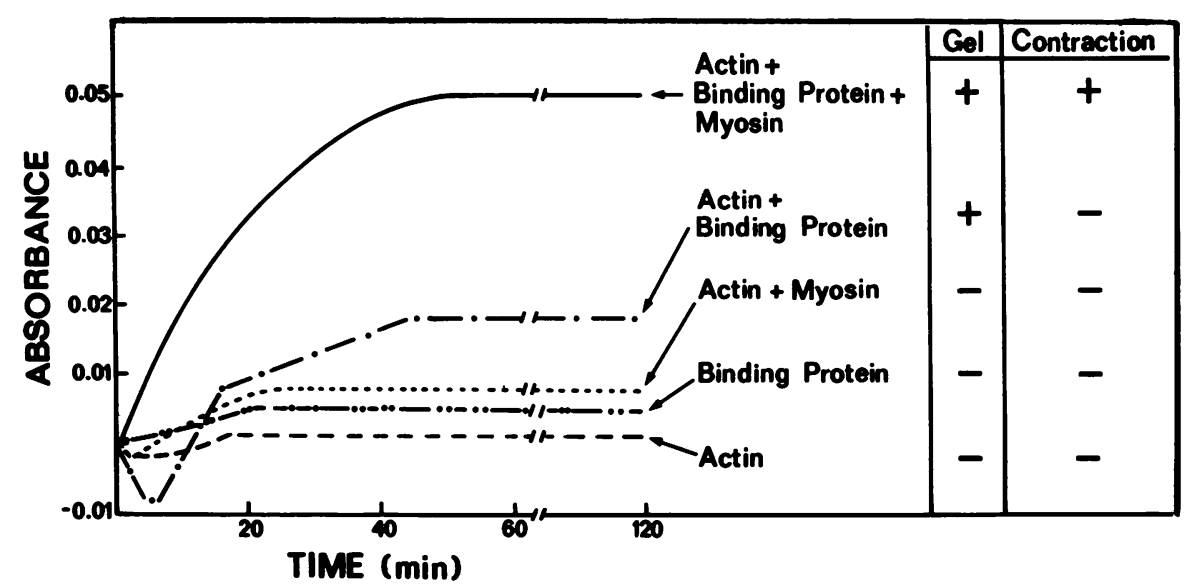

FIGURE 10 Effect of warming on the turbidity, consistency and movement of various combinations of purified CML actin-binding protein, CML myosin, and rabbit skeletal muscle Gactin in sucrose solution. The proteins were dialyzed into sucrose solution and their concentrations determined. At zero time, the ice-cold proteins were incubated at $25^{\circ} \mathrm{C}$ in $0.3 \mathrm{ml}$ of sucrose solution. The protein concentrations were: actin, $0.83 \mathrm{mg} / \mathrm{ml}$, actin-binding protein, $0.33 \mathrm{mg} / \mathrm{ml}$, and myosin, $0.29 \mathrm{mg} / \mathrm{ml}$. Gelation (solidification of the solution) and/or final contraction (aggregation of the gel) occurred where indicated.

Contraction did not occur (Fig. 10). A combination of either muscle actin or CML actin with CML myosin and CML actin-binding protein also gelled during warming, and greater increases in turbidity occurred than with any of the other combinations. When CML actin or skeletal muscle actin, CML myosin, and CML actin-binding protein were allowed to stand overnight, final contraction occurred.

The turbidity acquired by CML actin-binding protein in sucrose solution during warming was reversed by cooling. This reversibility was not observed with rabbit skeletal muscle $\mathrm{F}$-actin.

Behavior of the extract supernate and purified CML leukocyte proteins in the presence of antisera. Preincubation of the extract supernate with nonimmune rabbit serum in the cold for $10 \mathrm{~min}$ had no effect on the turbidity of extract supernatants. But with warming from $0^{\circ}$ to $25^{\circ} \mathrm{C}$, the turbidity increased more rapidly and the rate of gelation and final contraction was more rapid than seen in the extract supernate without added serum (Fig. 11). When the extract supernate was incubated at $0^{\circ} \mathrm{C}$ with rabbit serum containing antibodies against CML myosin and warmed to $25^{\circ} \mathrm{C}$, the increase in turbidity was less than that of the extract supernate containing nonimmune rabbit serum. Gelation occurred, but the onset of final contraction was delayed and its extent diminished. Anti-CML myosin antiserum also decreased the amount of turbidity resulting from warming a mixture of purified CML actin, CML myosin, and CML actin-binding protein. The very gradual final contraction of the gel which ensued in this mixture in the presence of nonimmune rabbit serum did not occur in the presence of the anti-
CML myosin antiserum (Fig. 12). Incubation of the rabbit serum containing antibody against CML actinbinding protein with the extract supernate inhibited completely both the rise in turbidity and gelation during

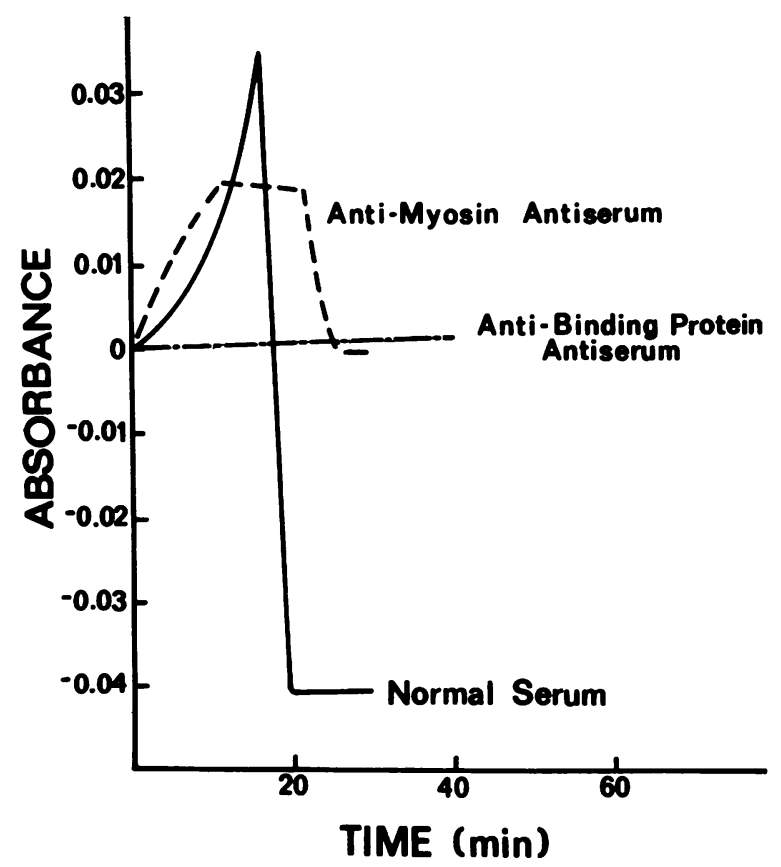

Figure 11 Effect of nonimmune rabbit serum or rabbit antiserum to $\mathrm{CML}$ myosin or $\mathrm{CML}$ actin-binding protein on the turbidity of a CML leukocyte extract. $6 \mathrm{vol}$ of the extract supernate was incubated with 1 vol of the respective rabbit sera at $0^{\circ} \mathrm{C}$ for $10 \mathrm{~min}$. At zero times indicated, the supernates were incubated at $25^{\circ} \mathrm{C}$. The abrupt decrease in absorption was associated with final contraction of the gel.

Interactions of Leukemic Contractile Proteins 


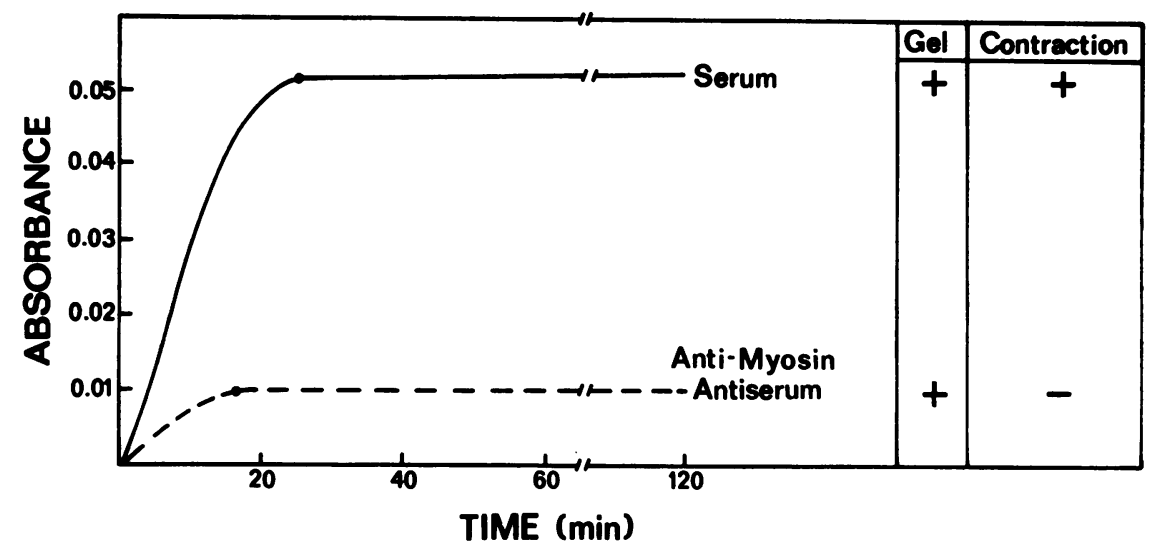

FIGURE 12 Effect of nonimmune rabbit serum and rabbit antiserum to CML myosin on the turbidity, gelation (solidification), and contraction (aggregation) of a mixture of CML actin, actin-binding protein, and myosin. The purified proteins were incubated in $0.4 \mathrm{ml}$ of sucrose solution with $0.15 \mathrm{ml}$ of the indicated sera for $10 \mathrm{~min}$ at $0^{\circ} \mathrm{C}$. At zero time the ice-cold proteins were incubated at $25^{\circ} \mathrm{C}$. The protein concentrations were: CML actin-binding protein, $0.3 \mathrm{mg} /$ $\mathrm{ml}, \mathrm{CML}$ G-actin, $0.8 \mathrm{mg} / \mathrm{ml}$, and CML myosin, $0.3 \mathrm{mg} / \mathrm{ml}$.

warming. The effect of anti-CML actin-binding protein antiserum on purified proteins was not studied.

Morphology of CML cells, extracts, and purified proteins. The morphology of glutaraldehyde fixed CML extract gels in thin sections was similar in appearance to the thin sections of intact CML leukocytes. Both contained randomly oriented filaments measuring $6-8 \mathrm{~nm}$ in diameter (Fig. 13). When thin sections were made of a contracting aggregate formed from purified CML actin, CML myosin, and CML actin-binding protein, and examined in the electron microscope, filaments of a similar diameter to those found in the extract supernate were also seen (Fig. 13).

CML extracts or else a mixture of purified CML actin, CML myosin, and CML actin-binding protein were allowed to gel for $200 \mathrm{~min}$ at $25^{\circ} \mathrm{C}$ and collected by low-speed centrifugation. The gelatinous pellets were gently disrupted at $25^{\circ} \mathrm{C}$ with 100 vol of $0.1 \mathrm{M} \mathrm{KCl}, 20$
$\mathrm{mM}$ Tris-maleate, $\mathrm{pH} 7.0$, in a Dounce homogenizer, and samples were negatively stained and examined in the electron microscope (Fig. 14). The over-all appearance in both cases was that of tangled filaments. The morphology of the filaments was most clearly seen in the purified preparations where the filaments had less associated debris than in the crude extract aggregates. Individual filaments $5-7 \mathrm{~nm}$ in diameter were often paired. Distinct myosin filaments were not discernible.

\section{DISCUSSION}

The contractile proteins of $C M L$ and other granulocytes (a) Actin. Histochemical techniques have identified 6-8-nm filaments of normal human and horse neutrophils as F-actin $(7,8)$. Neutrophils rendered permeable to the muscle myosin fragment, heavy meromysin, have randomly oriented straight filaments with characteristic arrowheads. Purified CML and horse
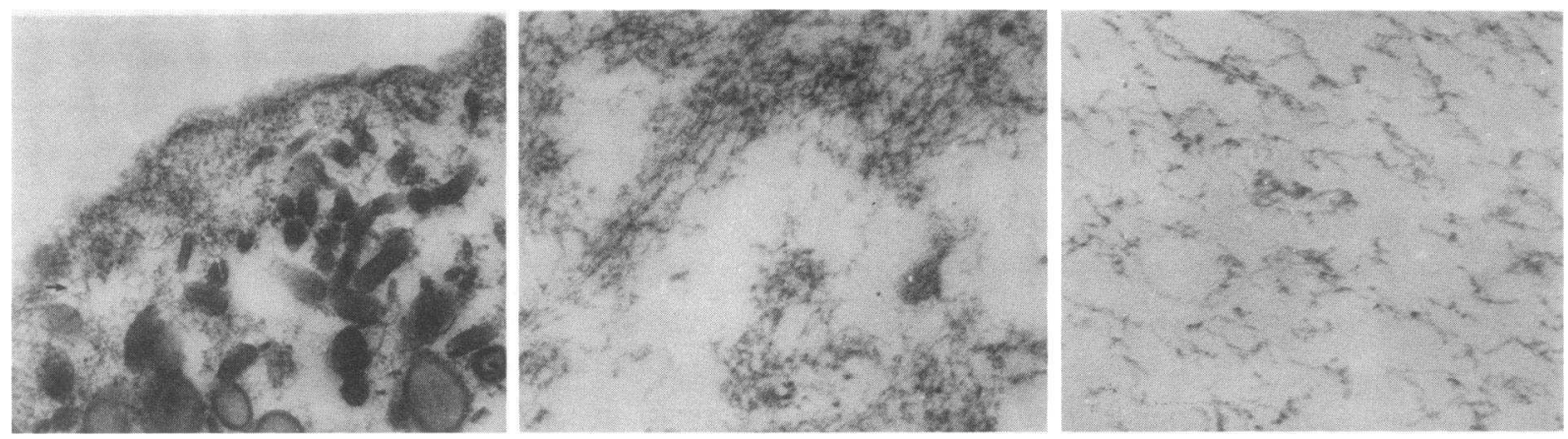

FIGURE 13 Ultrastructure of thin sections of (left) intact CML leukocytes, the arrow indicates a representative thin filament. (Middle) CML leukocyte extract supernate gelled at $25^{\circ} \mathrm{C}$. and (right) a gel formed from purified CML actin, CML myosin, and CML actin-binding protein at $25^{\circ} \mathrm{C}$. Original magnifications: left, $\times 38,000$; middle, $\times 127,000$; right, $\times 127,000$. 

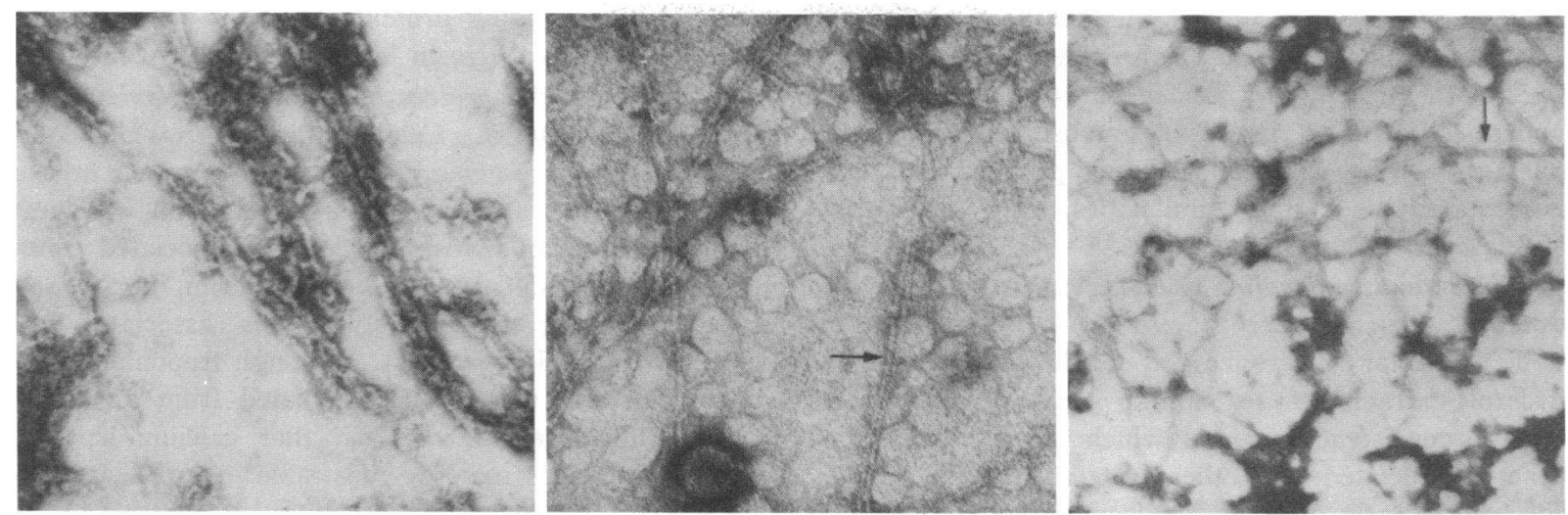

FIGURE 14 Morphology of negatively stained (left) gelled CML leukocyte supernate; (middle) gel of purified CML actin plus CML actin-binding protein; (right) gel of purified CML actin plus CML actin-binding protein plus $\mathrm{CML}$ myosin in $0.1 \mathrm{M} \mathrm{KCl}$. Representative examples of parallel filaments are indicated by arrows. Original magnifications: left, $\times 82,000$; middle, $\times 130,000$; right, $\times 127,000$.

leukocyte actins resemble skeletal muscle actin by their morphology, ability to polymerize in $\mathrm{KCl}$, and, in the polymerized state, to activate skeletal muscle myosin $\mathrm{Mg}^{2+}$-ATPase activity (8).

(b) Myosin. Like other vertebrate myosins, guinea pig neutrophil, horse leukocyte, and CML myosin form thick filaments in $0.1 \mathrm{M} \mathrm{KCl}$, and have $\mathrm{K}^{+}$- and EDTAactivated and $\mathrm{K}^{+}$- and $\mathrm{Ca}^{2+}$-activated ATPase activities $(4,6)$. The subunit structure of CML and guinea pig neutrophil myosins consists of heavy chains and two sets of light chains (6).

The purified CML myosin had a lower apparent Stokes radius and a lower heavy-chain molecular weight than rabbit skeletal muscle and guinea pig neutrophil myosins. Although CML myosin may be a smaller molecule than the other myosins, the finding that the heavy chain band was heavier in extract supernates than in the purified protein suggests that CML myosin was degraded variably during purification, and such degradation may account for the low yields of myosin obtained. When the extract supernate was allowed to stand overnight at $4^{\circ} \mathrm{C}, \mathrm{K}^{+}$- and EDTA-activated ATPase activity eluted much later from the agarose columns than usual. The myosin fragment had enzymatic activities characteristic of CML myosin but, like enzymatically active skeletal muscle fragments, it was soluble in low ionic strength buffer, pH 7.0 (23). Human neutrophils, including CML neutrophils, contain neutral proteases, which are not inhibited by EDTA and which digest various proteins (24). The neutral proteases released from lysosomes of the leukocytes during homogenization were probably responsible for removing part of the rod portion of the CML myosin molecule. Human platelet myosin is also purified, in part, in a degraded state $(25,26)$.
One of the proteins associated with actin undergoing gelation in crude CML extracts was a high molecular weight molecule which resembled an actin-binding protein isolated from rabbit alveolar macrophages with respect to electrophoretic mobility on polyacrylamide gels in dodecyl sulfate, elution profile from agarose columns, insolubility in $5 \mathrm{mM} \mathrm{CaCl}$ solution, and its binding to actin at physiologic $\mathrm{pH}$ and ionic strength $(20,21,27)$. Like purified rabbit alveolar macrophage actin-binding protein, it either co-migrated during electrophoresis with dodecyl sulfate with the lighter polypeptide of the doublet comprising purified human erythrocyte spectrin $(20,28)$ or else with a slower mobility than either spectrin subunit (21). Again, proteolysis may account for these variations. In light of its similarities to macrophage actin-binding protein, we have designated the CML protein a CML actin-binding protein.

It is of interest to compare spectrin with the high molecular weight actin-binding protein of CML leukocytes since $(a)$ spectrin is also a high molecular weight protein; (b) CML actin-binding protein is water soluble and, like rabbit erythrocyte spectrin, chromatographs on agarose columns in at least two states of aggregation and with the same elution volumes $(20)$; and $(c)$ spectrin is associated with actin in the erythrocyte (29). A protein with a subunit composition resembling that of spectrin has been identified in association with actin in echinoderm sperm (30). However, in contrast to erythrocyte spectrin, the CML actin-binding protein yielded a single band after polyacrylamide gel electrophoresis in dodecyl sulfate rather than the two associated with spectrin and the echinoderm sperm protein. Immunochemical analysis revealed that antisera to CML actin-binding protein, myosin, and human erythrocyte

Interactions of Leukemic Contractile Proteins 
spectrin only reacted against their respective antigens. Antibodies against human erythrocyte spectrin failed to react with proteins in homogenates of a variety of human cells (31). All of these observations indicate that although myosin, actin-binding proteins, and spectrins may have certain similarities, they are distinct proteins.

Gelation and contraction of CML extracts and purified proteins. Ice-cold sucrose extracts of Acanthamoeba, rabbit alveolar macrophages, CML leukocytes, and glycerol extracts of sea urchin eggs when warmed, undergo consistency changes which are due to gelation of actin associated with other proteins $(21,32,33,34)$. The extract gels of CML leukocytes are composed of interdigitating thin filaments resembling the periphery of intact cells. The extract gels contain actin as a major component. Among other proteins is the new polypeptide which has been purified from rabbit alveolar macrophages and CML leukocytes and designated an actin-binding protein. In rabbit alveolar macrophages and CML leukocytes, purified actin-binding protein causes actin to gel in warmed sucrose solutions suggesting that the actin-binding protein is responsible for promoting the gelation of actin under these conditions. CML leukocyte and rabbit alveolar macrophage actinbinding proteins aggregate when warmed and disaggregate in the cold. CML leukocyte and rabbit alveolar macrophage-supernatant extract gels liquify when cold, and no F-actin is detectable in the liquified extracts by electron microscopy or sedimentation analysis. An interpretation of these findings is that warming of the actin-binding protein causes it to initiate polymerization and cross-linking of actin in a manner that is reversed by cooling.

Warmed crude sucrose extracts of Acanthamoeba, rabbit macrophage, and $\mathrm{CML}$ leukocytes containing $\mathrm{Mg}^{2+}$-ATP contract after gelation (21, 32). Rabbit alveolar macrophage and CML leukocyte myosin in the presence of $\mathrm{Mg}^{2+}$-ATP generate contractions of their respective actin-binding protein-actin gels. The contraction is different from the superprecipitation or contraction of skeletal muscle actomyosin described long ago (35) only with respect to the state of the starting material: a solid actin plus actin-binding protein gel rather than a thixotropic actomyosin gel. The results of experiments with antisera against CML leukocyte proteins provide further evidence for the formulations just summarized. Antiserum against CML leukocyte actinbinding protein but not antiserum against CML myosin inhibits gelation of CML leukocyte extracts confirming the hypothesis that actin-binding protein is required for gelation of CML leukocyte actin. Antiserum against CML leukocyte myosin has not effect on gelation but partially curtails the contraction of extract gels and purified actin-binding protein and actin gels, consistent with the idea that myosin is responsible for contraction.

Control of CML protein interactions and relevance to leukocyte movement. Calcium ion controls the $\mathrm{Mg}^{2+}$ ATPase and force-generating activity of muscle myosins in the presence of $\mathrm{F}$-actin by its interaction with regulatory subunits of myosin, with actin-associated control proteins, the troponins, and tropomyosin, or, in some cases, with regulatory polypeptides associated with both myosin and actin (36). Although troponins or tropomyosin have not yet been isolated from any leukocytes, Shibata et al. reported that calcium-dependent turbidity changes were demonstrable in crude actomyosin preparations from mixed equine leukocytes (4), and $\mathrm{Hsu}$ and Becker observed calcium-dependent as well as calcium-independent shape changes in glycerinated rabbit neutrophils (34). Neither the gelation or contraction of crude CML extracts in our studies were inhibited by EGTA, suggesting that factors conferring calcium regulation were not present in these extracts. Whether calcium indeed regulates contractile activity in CML leukocytes, and the factors conferring calcium regulation were lost or inactivated remain to be determined. However, there is evidence that novel mechanisms exist in certain cells which influence the $\mathrm{Mg}^{2+}$-ATPase activity of actomyosin, the enzymatic activity which is relevant for contractile activity. In Acanthamoeba (37) and in rabbit macrophages (27), proteins called cofactors are required for activation of myosin $\mathrm{Mg}^{2+}$-ATPase activity by actin. In platelets, a protein kinase concomitantly phosphorylates a myosin light subunit and activates the $\mathrm{Mg}^{2+}$-ATPase of platelet actomyosin (38). The rate of contraction of rabbit macrophage actin plus actin-binding protein gels is accelerated by rabbit macrophage cofactor (21). The findings suggest that the activating effect of the cofactor on myosin enzymatic activity is expressed mechanically as well. We have no evidence yet that a similar cofactor is operative in CML leukocytes. However, one interpretation of the feeble activation of CML myosin $\mathrm{Mg}^{2+}$-ATPase activity by actin and of the discrepancy in contraction rates between crude CML leukocyte extracts and mixtures of purified CML proteins is that a cofactor is missing from the reconstituted systems.

Actin in skeletal muscle always exists in a polymerized state. Actin filaments activate myosin, and the activated myosin transduces the energy in ATP into mechanical force, which causes actin filaments to slide concomitant with the hydrolysis of ATP (39). However, in neutrophils reversible pseudopod formation may be associated with the assembly of localized filament networks, since neutrophil pseudopodia are filled with these filaments (40). The extension and retraction of pseudopodia in neutrophils could be explained 
in part by reversible assembly and contraction of gelled actin filaments. Polymerization of cytoplasmic actin has been suggested to account for extension of the acrosomal process of echinoderm and arthropod sperm (41, 42). The neutrophils of an infant, who had recurrent bacterial infections were markedly deficient in locomotion and ingestion, and the regulation of their granule secretion was defective. Actin in extracts of these cells polymerized incompletely relative to actin in extracts from normal neutrophils (7). The impaired actin polymerization was invoked to explain the defects in locomotion and ingestion. Accelerated degranulation both into the extracellular medium and into phagosomes was hypothesized to result from the failure of actin filament barriers to form which normally prevent uncontrolled granule fusion with plasma membranes and with phagosomes. The findings were consistent with the idea that reversible polymerization of actin in neutrophils is involved in several aspects of neutrophil behavior. The discovery of an agent, actin-binding protein, that controls the reversible temperature-dependent formation of actin gels resembling the morphology of cytoplasm in vivo and which are contracted by myosin may provide some rudimentary insight into the mechanism of neutrophil filament assembly, and movement.

\section{ACKNOWLEDGMENTS}

We thank Ms. Ann Ballen for technical assistance, Mrs. Catherine Lewis for help with the manuscript, Dr. E. Tessa Hedley-Whyte for use of the electron microscope, and Dr. Joel Rappeport for allowing us to study his patients.

This work was supported by U.S. Public Health Service grant HL-17742.

\section{REFERENCES}

1. De Bruyn, P. P. H. 1946. The amoeboid movement of the mammalian leukocyte in tissue culture. Anat. Rec. 95: 177-191.

2. McCutcheon, M. 1946. Chemotaxis in leukocytes. Physiol. Rev. 26: 319-336.

3. Senda, N., N. Shibata, N. Tatsumi, K. Kondo, and K. Hamada. 1969. A contractile protein from leucocytes. Its extraction and some of its properties. Biochim. Biophys. Acta. 181: 191-200.

4. Shibata, N., N. Tatsumi, K. Tanaka. Y. Okamura, and N. Senda. 1972. A contractile protein possessing $\mathrm{Ca}^{2+}$ sensitivity (natural actomyosin) from leukocytes. Its extraction and some of its properties. Biochim. Biophys. Acta. 256: 565-576.

5. Tatsumi, N., N. Shibata, Y. Okamura, K. Takeuchi, and N. Senda. 1973. Actin and myosin A from leucocytes. Biochim. Biophys. Acta. 305: 433-444.

6. Stossel, T. P., T. D. Pollard. 1975. Myosin in polymorphonuclear leukocytes. J. Biol. Chem. 248: 82888294.

7. Boxer, L. A., E. T. Hedley-Whyte, and T. P. Stossel. 1974. Neutrophil actin dysfunction and abnormal neutrophil behavior. N. Engl. J. Med. 291: 1093-1099.

8. Senda, N., H. Tamura, N. Shibata, J. Yoshitake, K. Kondo, and K. Tanaka. 1975. The mechanism of the movement of leucocytes. Exp. Cell Res. 91: 393-407.
9. Boxer, L. A., and T. P. Stossel. 1975. Isolation and interactions of contractile proteins from chronic myelogenous leukemia granulocytes (CMLG). J. Cell Biol. 67: 40a. (Abstr.)

10. Buckner, D., R. G. Graw, Jr., R. J. Eisel, E. S. Henderson, and S. Perry. 1969. Leukapheresis by continuous flow centrifugation in patients with chronic myelocytic leukemia. Blood. 33: 353-369.

11. Stossel, T. P. 1973. Evaluation of opsonic and leukocyte function with a spectrophotometric test in patients with infection and with phagocytic disorders. Blood. 42: 121-130.

12. Spudich, J. A., and S. Watt. 1971. The regulation of rabbit skeletal muscle contraction. I. Biochemical studies of the interaction of the tropomyosintroponin complex with actin and the proteolytic fragments of myosin. $J$. Biol. Chem. 246: 4866-4871.

13. Pollard, T. D., S. M. Thomas, and R. Niederman. 1974. Human platelet myosin. I. Purification by a rapid method applicable to other nonmuscle cells. Anal. Biochem. 60: 258-266.

14. Kielley, W. W., and L. B. Bradley. 1956. The relationship between sulfhydryl groups and the activation of myosin adenosinetriphosphate. J. Biol. Chem. 218: 653659.

15. Richards, E. G., C-S. Chung, D. B. Menzel, and H. S. Olcott. 1967. Chromatography of myosin on diethylaminoethyl-Sephadex A-50. Biochemistry. 6: 528-540.

16. Lowry, O. H., N. J. Rosebrough. A. L. Farr, and R. J. Randall. 1951. Protein measurement with the Folin phenol reagents. J. Biol. Chem. 193: 265-275.

17. Craven, G. R., E. Steers, Jr., and C. B. Anfinsen. 1965. Purification, composition, and molecular weight of the $\beta$-galactosidase of Escherichia coli K12. J. Biol. Chem. 240: 2468-2477.

18. Fairbanks, G., T. L. Steck, and D. F. H. Wallach. 1971. Electrophoretic analysis of the major polypeptides of the human erythrocyte membranes. Biochemistry. $10: 2606-2617$.

19. Weber, K., and M. Osborn. 1969. The reliability of molecular weight determinations by dodecyl sulfatepolyacrylamide gel electrophoresis. J. Biol. Chem. 244 : 4406-4412.

20. Hartwig, J. H., and T. P. Stossel. 1975. Isolation and properties of actin, myosin, and a new actin-binding protein in rabbit alveolar macrophages. J. Biol. Chem. 250: 5696-5705.

21. Stossel, T. P., and J. H. Hartwig. 1976. Interactions of actin, myosin and a new actin-binding protein of rabbit pulmonary macrophages II. Role of actin-binding protein in cytoplasmic movement and phagocytosis. J. Cell Biol. 68: 602-619.

22. Lowey, S., and L. A. Steiner. 1972. An immunochemical approach to the structure of myosin and the thick filament. J. Mol. Biol. 65: 111-126.

23. Lowey, S., H. S. Slayter, A. G. Weeds, and H. Baker. 1969. Substructure of the myosin molecule. I. Subfragments of myosin by enzymic degradation. J. Mol. Biol. 42: 1-29.

24. Ohlsson, K., and I. Olsson. 1973. The neutral proteases of human granulocytes. Isolation and partial characterization of two granulocyte collagenases. Eur. J. Biochem. 36: 473-481.

25. Adelstein, R. S., T. D. Pollard, and W. M. Kuehl. 1971. Isolation and characterization of myosin and two myosin fragments from human blood platelets. Proc. Natl. Acad. Sci. U. S. A. 68: 2703-2707. 
26. Abramowitz, J., A. Stracher, and T. C. Detwiler. 1974. Proteolysis of myosin during platelet storage. J. Clin. Invest. 53: 1493-1496.

27. Stossel, T. P., and J. H. Hartwig. 1975. Interactions between actin, myosin and a new actin-binding protein of rabbit alveolar macrophages. Alveolar macrophage myosin $\mathrm{Mg}^{2+}$-adenosine triphosphatase requires a cofactor for activation by actin. J. Biol. Chem. 250: 5706-5712.

28. Marchesi, S. L., E. Steers, V. T. Marchesi, and T. W. Tillack. 1970. Physical and chemical properties of a protein isolated from red cell membranes. Biochemistry. 9: 50-57.

29. Tilney, L. G., and P. Detmers. 1975. Actin in erythrocyte ghosts and its association with spectrin. Evidence for a non-filamentous form of these two molecules in situ. J. Cell Biol. 66: 508-520.

30. Tilney, L. G. 1974. Non-filamentous aggregates of actin in sperm: a new state of actin. J. Cell Biol. 63: 349a. (Abstr.)

31. Painter, R. G., M. Sheetz, and S. J. Singer. 1975. Detection and ultrastructural localization of human smooth muscle myosin-like molecules in human nonmuscle cells by specific antibodies. Proc. Natl. Acad. Sci. U. S. A. 72 : 1359-1363.

32. Pollard, T. D. 1976. The role of actin in the temperature-dependent gelation and contraction of Acanthamoeba extracts. J. Cell Biol. 68: 579-601.

33. Kane, R. E. 1975. Preparation and purification of polymerized actin from sea urchin egg extracts. J. Cell Biol. 66: 305-315.

34. Hsu, L. S., and E. L. Becker. 1975. Volume decrease of glycerinated polymorphonuclear leukocytes mduced by ATP and $\mathrm{Ca}^{2+}$. 1. Resemblances to actomyosin contraction. Exp. Cell Res. 91: 469-473.

35. Szent-Györgyi, A. 1947. Chemistry of Muscular Contraction. Academic Press, Inc., New York. 150 p.

36. Lehman, W., and A. G. Szent-Györgyi. 1975. Regulation of muscular contraction. Distribution of actin control and myosin control in the animal kingdom. J. Gen. Physiol. 66: 1-30.

37. Pollard, T. D., and E. D. Korn. 1973. Acanthamoeba myosin. II. Interaction with actin and a new cofactor protein required for actin activation of $\mathrm{Mg}^{2+}$-adenosine triphosphatase activity. J. Biol. Chem. 248: 4691-4697.

38. Adelstein, R. S., and M. A. Conti. 1975. Phosphorylation of platelet myosin increases actin-activated myosin ATPase activity. Nature (Lond.). 256: 597-598.

39. Huxley, H. E. 1969. The mechanism of muscular contraction. Recent structural studies suggest a revealing model for cross-bridge action at variable filament spacing. Science (Wash. D. C.). 164: 1356-1366.

40. Keyserlingk, D. G. 1968. Elektronenmikroskopische Untersuchung über die Differenzierungsvorgänge im Cytoplasma von segmentierten neutrophilen Leukozyten während der Zellbewegung. Exp. Cell Res. 51: 79-91.

41. Tilney, L. G., S. Hatano, H. Ishikawa, and M. S. Mooseker. 1973. The polymerization of actin: its role in the generation of the acrosomal process of certain echinoderm sperm. J. Cell Biol. 59: 109-126.

42. Tilney, L. G. 1975. Actin filaments in the acrosomal reaction of Limulus sperm. Motion generated by alterations in the packing of the filaments. J. Cell Biol. 64: 289-310. 